\title{
ALTERED FORAGING BEHAVIOR UNDER VARYING FOOD QUALITY: DOES INCREASED FEEDING EFFICIENCY MEDIATE THE INVASION SUCCESS OF THE SNAIL, POTAMOPYRGUS ANTIPODARUM?
}

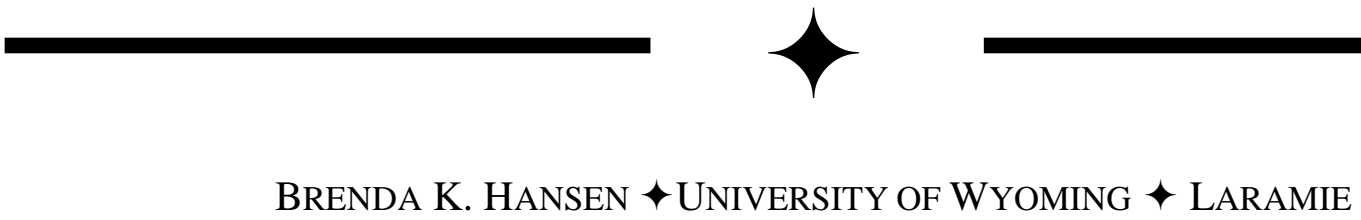

\section{$\uparrow \quad$ ABSTRACT}

Resource competition can shape the species composition of an ecosystem. In environments where nutrients are limited in either quantity or quality, the organisms best equipped to exploit these resources may gain a competitive advantage. The New Zealand mudsnail (Potamopyrgus antipodarum), a successful invader of the Greater Yellowstone Ecosystem, may benefit from such an advantage. Potamopyrgus antipodarum is a parthenogenetic snail, with high growth rates, and a high percent of somatic phosphorus (P). Consequently, these snails should have a high demand for P. Because freshwater ecosystems are often limited in P, successful animals like $P$. antipodarum must be exceptionally efficient at acquiring $\mathrm{P}$ from their food, either through effective foraging or digestive efficiency. We conducted experiments comparing the feeding rate and foraging preference of $P$. antipodarum and the coexisting native snail, Fossaria sp., under two levels of P (low and high). We conducted additional experiments to examine how foraging preference is altered by the presence of conspecific and heterospecific interactors. Both species consumed low $\mathrm{P}$ food at a higher rate than high $\mathrm{P}$ food. However, only Fossaria preferred high $\mathrm{P}$ food when given a choice between patch quality, and only exhibited this preference when they alone. Additional experiments are needed to further explore the foraging behavior of these two species, and to determine if these differences mediate the invasion success of $P$. antipodarum.

\section{$\downarrow \quad$ INTRODUCTION}

The propagation of genetic material is the evolutionary driver for all species. To successfully pass on its genetic material, an animal must both survive long enough to reproduce, and reach reproductive size (or age), which requires a diet adequate in quantity and quality. As many environments are limited in food quality (Cross et al. 2005), understanding how organisms cope with dietary limitation is essential to construe population and community-level interactions, and ecosystem function. Understanding these coping mechanisms may be important when examining interactions among organisms at different trophic levels, as nutrient ratios are often mismatched between consumers and their resources, which becomes more pronounced with increasing phylogenetic distance (Sterner and Elser 2002). Ecological stoichiometry, the balance of elemental nutrients between organisms and their environment (Sterner and Elser 2002), is a valuable tool to assess the quality of available resources. Ecological stoichiometry focuses on ratios of the elements carbon (C), nitrogen (N) and phosphorus $(\mathrm{P})$, as they are critical to the function of all living organisms and comprise the largest proportion of an animal's dry mass (Sterner and Elser 2002). Carbon limitation occurs when the available quantity of food is limited. In contrast, $\mathrm{N}$ and $\mathrm{P}$ limitation occurs when available forage is poor in quality. Nitrogen is the primary component of amino acids and is thus important for protein production, while $\mathrm{P}$ is a major component of nucleic acids (DNA and RNA), making both elements critical for organism growth and reproduction (Sterner and Elser 
2002). Because both $\mathrm{N}$ and $\mathrm{P}$ are limiting resources in many ecosystems (Sterner and Elser 2002, Cross et al. 2005), increased competitive interactions within and between species could lead to dominance by species that are better adapted to cope with limitation (Tilman 1982). This potential for a change in species composition due to competitive interactions may be of particular concern in cases where successful invaders colonize and dominate sensitive habitats. Ecological stoichiometry can help evaluate how invasive species may impact a native community by investigating potential changes in nutrient availability and competition for resources.

Growth rate is directly related to somatic ribonucleic acid (RNA) content, because ribosomal RNA is required to make proteins. Consequently, in invertebrates there is a positive relationship between the amount of RNA and somatic P (Elser et al. 1990). This "Growth Rate Hypothesis" states that animals with high growth rates will have relatively low $\mathrm{C}: \mathrm{P}$ ratios, because of the high levels of RNA required to support rapid growth (Elser et al. 1990, Sterner and Elser, 2002). High growth rates may facilitate invasion success by allowing organisms to reach reproductive maturity at a younger age, thus producing more generations in a given time (Stearns 1992). However, high growth rates come at the cost of an increased demand for dietary P. High $\mathrm{P}$ requirements of animals with elevated growth rates can be achieved by physiological and behavioral mechanisms. When faced with limited quantity or quality of nutrients, an animal may preferentially feed on high quality patches, or simply consume more food in lower quality patches (Fink and Von Elert 2006). The ability to select higher quality forage is dependent on the ability of the animal to distinguish between patches varying in quality, which may require specialized sensory structures. An animal's foraging behavior may also be altered by the presence of potential conspecific or heterospecific interactors (Peckarsky 1996, Cope and Winterbourn 2004, Brenneis et al. 2010). Physiological responses to nutrient limitation include an increase in the retention time of food within the digestive system (which increases exposure to digestive enzymes and time for absorption) and an increase in key digestive enzyme production, thereby increasing digestive efficiency (Darchambeau 2005). For example, in a P-limited environment, several invertebrate species increase levels of alkaline phosphatase (AP), a digestive enzyme that cleaves phosphate molecules (Boavinda and Heath 1984, Bei-ping and Kang-sen 2003, McCarthy et al. 2010). Animals can improve their ability to process low-quality foods by combining more than one of these mechanisms, although physiological constraints prevent the concomitant increase of feeding rate and gut retention time. Superior foraging efficiency may contribute to the success of many invasive species in nutrient limited environments. Understanding how invasive species dominate native ecosystems is particularly important to the protection of sensitive native ecosystems, like those found in the Greater Yellowstone Ecosystem (GYE).

We compared the foraging behavior of an invasive snail (Potamopyrgus antipodarum, the New Zealand mudsnail), and a co-occurring native snail (Fossaria sp.) from streams of the GYE. Because $P$. antipodarum possesses high growth rates and high somatic P content (Tibbets et al. 2010), we expected that they should have a higher demand for $\mathrm{P}$ relative to potentially competing native animals with slower growth rates, like Fossaria (Thon and Krist forthcoming). We examined feeding rate and foraging preference for each species under two levels of dietary P. If $P$. antipodarum possesses mechanisms to cope more effectively with dietary $\mathrm{P}$ limitation, these traits may confer a competitive advantage over native grazers, and consequently may contribute to the invasive success of this snail.

\section{$\downarrow \quad$ METHODS}

\section{Experimental Diet}

To establish two levels of dietary $\mathrm{P}$, we cultured the green algae, Scenedesmus acutus, in separate flasks with a nutrient medium containing identical $\mathrm{N}$ and either low $(\mathrm{C}: \mathrm{P} \sim 1,119)$ or high $(\mathrm{C}: \mathrm{P}$ 203) amounts of $P$, so that the low $P$ treatment contained a C:P ratio five times greater than the high $P$ treatment (Dobberfuhl and Elser 1999). For each culture, we concentrated all of the harvested algae from one week and pipetted aliquots $(0.25 \mathrm{~mL}$ for preference and $2 \mathrm{~mL}$ for feeding rate) of the solution into aluminum weigh boats. To ensure adhesion of the algae, we scuffed the bottoms of the boats using a Dremel with 120 grit bits prior to adding food. We reserved a portion of the algae for elemental analysis. Although we have not completed this work, we will measure $\mathrm{P}$ in each culture using the standard ammonium-molybdate blue ascorbic acid method on a DU-64 Spectrophotometer (APHA 1992). Percent $\mathrm{C}$ and $\mathrm{N}$ will be measured using a $\mathrm{C} / \mathrm{N}$ analyzer at the University of Wyoming Stable Isotope Facility. 


\section{Study Animals}

Potamopyrgus antipodarum is a world-wide invasive snail with a high growth rate (Hall et al. 2006, Tibbets et al. 2010). Potamopyrgus antipodarum primarily feeds on periphyton (a biofilm growing on submerged substrata that is comprised primarily of algae, with bacteria and fungi) and detritus (Haynes and Taylor 1985). Despite their small size (3-5mm adults), in one invaded stream where $P$. antipodarum have reached a high population density, they consumed $75 \%$ of the gross primary productivity and contributed two-thirds of the ammonium demand via excretion (Hall et al. 2003). Potamopyrgus antipodarum was first observed in the Western United States in 1987 (Bowler 1991). In 1994, $P$. antipodarum was identified in the Greater Yellowstone Ecosystem (GYE) (Hall et al. 2003) and can occur at densities exceeding $500,000 / \mathrm{m}^{2}$ (Hall et al. 2006). In a field experiment, $P$. antipodarum negatively affected growth rates of the native, rare snail species, Pyrgulopsis idahoensis (Riley et al. 2008) and in a laboratory experiment, at high biomass levels that occur in the invaded range, $P$. antipodarum severely reduced growth of the native snail, Fossaria (Bakerlymnaea) bulimoides group (Thon and Krist forthcoming 2013). My experiments compared the foraging behavior of $P$. antipodarum and Fossaria.

We collected all of the animals from the GYE during the summer of 2011. All Potamopyrgus antipodarum $(3.5-5 \mathrm{~mm})$ were collected from lower Polecat Creek, near Flagg Ranch, using aquatic nets. Animals were transported $P$. antipodarum in damp paper towels placed on ice. We collected Fossaria sp. (7-10 mm) by hand, from the Snake River and, using aquatic nets, from a tributary of upper Polecat Creek on the Boundary Trail of Grand Teton and Yellowstone National Park. Fossaria sp. were transported in five gallon buckets filled with stream water. We froze 100 individuals of each species upon return for $\mathrm{C}: \mathrm{N}: \mathrm{P}$ analysis (see methods in "Experimental Diet). The remaining animals were housed in aquaria located in the UW Zoology and Physiology Animal Facility, under a 12 hour light cycle. We maintained the temperature at $23{ }^{\circ} \mathrm{C}$ and changed the stock water every three days. Prior to the experiment, animals were fed an ad libitum diet of organic leaf lettuce, goldfish flakes and algae pellets.

\section{Feeding Rate}

To determine whether either species compensates for low quality food by increasing feeding rate, we housed thirty replicates of each species in $300 \mathrm{~mL}$ chambers and provided a single boat containing a pre-weighed amount of low or high $P$ food. To ensure that a measurable amount of food was consumed, we used multiple animals in each replicate. Because individual Fossaria are approximately 15 times larger than individual $P$. antipodarum, we compared species treatments using equal biomass, rather than an equal numbers of individuals. To minimize intraspecific competition in the $P$. antipodarum treatments, we used $60 \%$ of the Fossaria biomass, so that each Fossaria replicate contained three individuals, while each $P$. antipodarum replicate contained 30 individuals. All snails fasted for three days prior to running experimental trials. Following a three-hour feeding period, we removed boats, placed them in a drying oven for 24 hours and re-weighed them to determine how much algae was consumed. We analyzed the data using one-way ANOVAs for each species, with $\mathrm{P}$ level as a fixed factor.

\section{Foraging Preference}

To determine whether either species preferentially feeds on high quality food, we placed an individual, marked snail (target) in $300 \mathrm{~mL}$ chambers and placed a single low $\mathrm{P}$ and single high $\mathrm{P}$ boat ( $3.5 \mathrm{~mm}$ diameter), evenly spaced in the center of the chamber. To determine whether foraging preference was altered by the presence of an interactor, we had three treatments for each species. In the first treatment, the target was alone, in the second and third treatments the target was with a single conspecific interactor or a single heterospecific interactor respectively. We recorded each eight-hour trial using a high definition video camera. For each trial, we documented the amount of time the target spent on each food type and, when present, the activity of the interactor. We calculated preference as:

We compared preference results to the null $(\arcsin \sqrt{ } 0.5)$ using a t-test. To determine whether foraging is altered by the presence of an interactor, we conducted a one-way ANOVA for each species with treatment as a fixed factor. 


\section{RESULTS}

\section{Feeding Rate}

Both Potamopyrgus antipodarum and Fossaria sp. consumed low phosphorus food at a greater rate than high $\mathrm{P}$ food during a three hour time period ( $P$. antipodarum: $\quad \mathrm{F}_{1,58}=181.5492 ; \mathrm{P}<$ 0.0001; Fossaria sp.: $\mathrm{F}_{1,48}=12.8993 ; \mathrm{P}=0.0008$; Figure 1). In both treatments, $P$. antipodarum consumed more food, per unit mass than Fossaria.

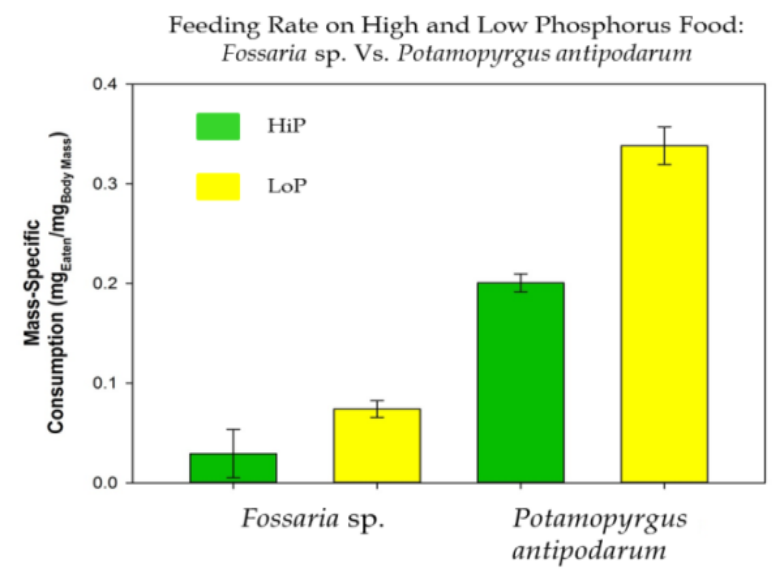

Figure 1. We provided the invasive snail, Potamopyrgus antipodarum (the New Zealand mudsnail), and the native snail, Fossaria sp., with diets of low (yellow) or high (green) phosphorus (P) algae (Scenedesmus acutus) for three hours. Both the invasive snail, $P$. antipodarum, and the native snail, Fossaria sp. consumed significantly more low $\mathrm{P}$ food (invasive: $\mathrm{F}_{1,58}=181.5492 ; \mathrm{P}<0.0001$; native: $\left.\mathrm{F}_{1,48}=12.8993 ; \mathrm{P}=0.0008\right)$.

\section{Feeding Preference}

Preliminary results from the feeding preference experiments were only conclusive for Fossaria sp. because only three replicates of $P$. antipodarum (two from the conspecific treatment and one from the heterospecific treatment) fed during the trials. When alone, Fossaria sp. exhibited a significant foraging preference for high $\mathrm{P}$ food $\left(\mathrm{T}_{21,1}\right.$ $=2.1254 ; \mathrm{P}=0.0228$; Figure 2), however Fossaria sp. showed no preference when a conspecific or heterospecific snail was present $\left(\mathrm{T}_{15},{ }_{1}=-0.7401 ; \mathrm{P}=\right.$ 0.7659 and $\mathrm{T}_{17,1}=0.950 ; \mathrm{P}=0.1777$ respectively). In addition to displaying preference for high $\mathrm{P}$ food, when alone, Fossaria spent significantly more time foraging than they did in the presence of a conspecific $\left(\mathrm{F}_{2,65}=3.6791 ; \mathrm{P}=0.0306\right.$; Figure 3$)$.

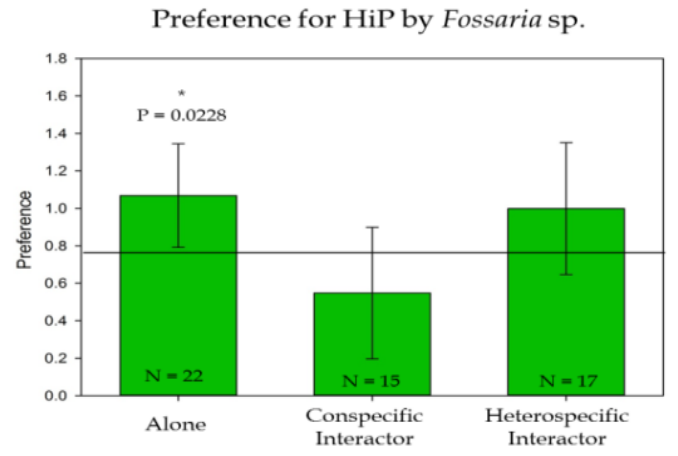

Figure 2. For three treatments (target alone, with a conspecific interactor or with a heterospecific interactor), I provided snails with a low and high phosphorus (P) food patch (aluminum weigh boats containing the algae Scenedesmus acutus) and measured the amount of time the target snail spent on each food type. Preliminary results suggest that Fossaria sp. displays significant preference for high $\mathrm{P}$ food $\left(\mathrm{T}_{21}=2.1254 ; \mathrm{P}=0.0228\right)$ only when alone. The dark line indicates no preference.

Time Spent Feeding By Fossaria sp.

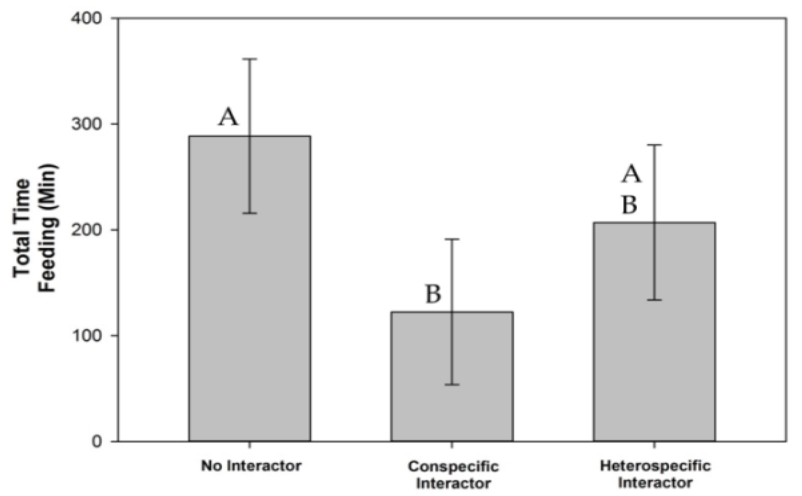

Figure 3. For three treatments (target alone, with a conspecific interactor or with a heterospecific interactor), we provided snails with a low and high phosphorus $(\mathrm{P})$ food patch (aluminum weigh boats containing the algae Scenedesmus acutus) and measured total amount of time that the target snail spent foraging. Preliminary results suggest that Fossaria sp. spend significantly more time feeding when they are alone than they do in the presence of a conspecific $\left(\mathrm{F}_{2,65}=3.6791 ; \mathrm{P}=0.0306\right)$.

\section{DISCUSSION}

Understanding the relationship between nutrient needs and the complex interactions occuring among species and their environments is especially important as we witness dramatic decreases in global biodiversity. Invasive species are among the leading threats to biodiversity (Sala et al. 2000), and ecosystems in the GYE are not immune to this threat 
(Hall et al. 2003). The invasive New Zealand mudsnail (Potamopyrgus antipodarum) has successfully invaded multiple habitat types all over the world, including several streams in the GYE, where it reaches high densities, consumes large quantities of resources and altered the local nitrogen cycle (Hall et al. 2003 and 2006). In addition to affecting native habitats, studies have demonstrated that $P$. antipodarum also impacts native species (Riley et al. 2008, Brenneis et al. 2010 and Thon and Krist forthcoming), including negative impacts on the native snail, Fossaria sp. (Krist and Dybdahl 2005, Thon and Krist, forthcoming). Diet may be a contributing factor to the invasion success of $P$. antipodarum (Krist and Charles 2012). Our preliminary results offer additional insight into the competitive ability of $P$. antipodarum, as well as possible mechanisms employed by Fossaria to compensate for limited $\mathrm{P}$.

The increased feeding rate of nutrient limited resources has been shown in several studies (Suzuki-Ohono et al. 2012). In nitrogen deficient environments the grasshopper, Omocestus viridulus, partially compensates by increasing feeding rate (Berner et al. 2005). In another study, the snail, Radix ovata, also responded to $\mathrm{N}$ and $\mathrm{P}$ limited food by increasing food consumption (Fink and von Elert 2006). In our experiments, both the invasive, $P$. antipodarum, and the native snail, Fossaria sp., also responded to low quality food by increasing their feeding rate. However, neither species was able to fully compensate for the difference in the low $\mathrm{P}$ diet by increasing feeding rate alone. To approximate the total amount of $\mathrm{P}$ intake possible in the high $\mathrm{P}$ treatment, each species would have needed to increase their rate of low $\mathrm{P}$ consumption by a factor of five. However, Fossaria only compensated for $50 \%$ of the difference in the low P treatment, while $P$. antipodarum did only slightly better by compensating for $66 \%$ of the difference in P. We will be able to provide a more accurate estimate of compensation when we complete the $\mathrm{C}: \mathrm{N}: \mathrm{P}$ analyses of both animal species. The higher total amount eaten by $P$. antipodarum relative to Fossaria under both food types is likely an artifact of an increased massspecific metabolic rate in the much smaller $(\sim 15$ times) P. antipodarum (Karasov and Martinez del Rio 2007).

In addition to compensatory feeding, some organisms are able to increase their feeding efficiency by preferentially consuming higher quality resources. Along with increased consumption of poor quality resources, when N-rich forage is available, $O$. viridulus will preferentially consume the higher quality food over the low quality food (Berner et al. 2005). Similar results have been found for zooplankters and caddisflies (Fulton 1988, Butler et al. 1989, Hart 1981). Consistent with these studies, my results suggest that Fossaria is able to distinguish between the quality of food patches (with respect to $\mathrm{P})$, which may enable it to compensate more fully in variable environments. While too few $P$. antipodarum fed in these experiments to make any conclusion about feeding preference, experiments that we conducted using a different algal species, the invasive snail displayed no apparent preference for high $\mathrm{P}$ over low $\mathrm{P}$ algae (Hansen, forthcoming). If $P$. antipodarum is unable to distinguish between the quality of food patches, they would need to employ additional physiological mechanisms to fully compensate for P limitation.

The presence of interactors may positively or negatively affect the foraging behavior of organisms (Brenneis et al. 2010). For instance, the presence of the aggressive blackfly larvae, Simulium virgatum, decreases the foraging activity of the midge, Blepharicera micheneri (Dudley et al. 1990). Our experiments suggest that Fossaria reduce feeding when a conspecific is present. In our experiments, pairs of Fossaria in individual chambers were very active and often followed each other. At the end of the trial, we found egg masses in several chambers, suggesting that the presence of conspecific interactors changed the focus of activity from foraging to breeding, and hence the decrease in feeding was not due to competition for resources. Also, the lack of preference in the Fossaria conspecific and heterospecific treatments may be an artifact of small sample sizes, rather than an actual change in feeding preference (15 and 17 respectively).

In additional experiments with another algae species as the food source, $P$. antipodarum increased their feeding time considerably in the presence of a conspecific (Hansen, forthcoming). It is possible that rather than experiencing increased competition, $P$. antipodarum is facilitated by certain densities of conspecific interactors. To address this possibility of facilitation, we will conduct additional experiments with varying levels of both conspecific and heterospecific interactors. We will also repeat the Feeding Preference experiment to confirm that $P$. antipodarum does not exhibit preference for high $\mathrm{P}$ food, and to assess the effects of interactors and density on the foraging behavior of both species. 


\section{CONCLUSIONS}

In our experiments, both the native snail, Fossaria sp., and the invasive snail, Potamopyrgus antipodarum partially compensate for phosphorusdeficient food by increasing their feeding rate. Additional experiments are needed to determine whether this behavior is similar when other nutrients are limited, and if either species is also employing other compensatory mechanisms, such as increased digestive enzyme production. As both species increase their feeding rate of low $\mathrm{P}$ food, it is unlikely that increased gut retention time is a factor. In addition to the compensatory feeding of low P food, Fossaria is also able to locate higher quality patches and preferentially feed on these higher quality resources, while $P$. antipodarum may to lack this ability.

\section{ACKNOWLEDGEMENTS}

This project would not have been possible without several fellowships offered the University of Wyoming's department of Zoology and Physiology, and the facilities available at the UW/NPS Research Station which helped to greatly decrease our overall travel costs. We are also grateful for all of the collecting help provided by our field friends and the continued support from Amy Krist and Carlos Martinez del Rio.

\section{$\uparrow \quad$ Literature Cited}

APHA. Standard methods for the examination of water and wastewater. 18th edn. Washington, D.C.: American Public Health Association; 1992.

Bei-ping T, Kang-sen M, Wei X. 2002. Availability of phosphorus from selected inorganic phosphates to juvenile abalone, Haliotis discus hannai Ino. Chinese Journal of Oceanology and Limnology. 20(2):118-128.

Berner D, Blanckenhorn WU, Körner C. 2005. Grasshoppers cope with low host plant quality by compensatory feeding and food selection: N limitation challenged. Oikos.111(3):525-533.

Boavinda MJ, Heath RT. 1984. Are the phosphatases released by Daphnia magna components of its food? Limnology and Oceanography. 29(3):641-645.
Bowler PA. 1991. The rapid spread of the freshwater hydrobiid snail Potamopyrgus antipodarum (Gray) in the middle Snake River, southern Idaho. Proceedings of the Desert Fishes Council. 21:173-179.

Brenneis VEF, Sih A, de Rivera CE. 2010. Coexistence in the intertidal: interactions between the non-indigenous New Zealand mud snail Potamopyrgus antipodarum and the native estuarine isopod Gnorimosphaeroma insulare. Oikos. 119:1755-1764.

Butler NM, Suttle CA, Neill WE. 1989. Discrimination by freshwater zooplankton between single algal cells differing in nutritional status. Oecologia. 78:368- 372 .

Cope NJ, Winterbourn MJ. 2004. Competitive interactions between two successful molluscan invaders of freshwaters: an experimental study. Aquatic Ecology. 38:83-91.

Darchambeau F. 2005 Filtration and digestion responses of an elementally homeostatic consumer to changes in food quality: a predictive model. Oikos. 111: 322-336.

Dobberfuhl DR, Elser JJ. 1999. Use of dried algae as a food source for zooplankton growth and nutrient release experiments. Journal of Plankton Research. 21: 957-970.

Dudley TL, Antonio CM.D', Cooper SD. 1990. Mechanisms and consequences of interspecific competition between two stream insects. Journal of Animal Ecology 59:849- 866 .

Elser JJ, Sterner RW, Gorokhova E, Fagan WF, Markow TA, Cotner, JB, Harrison JF, Hobbie SA, Odell GM, Weider LJ. 2000. Biological stoichiometry from genes to ecosystems. Ecology Letters. 3:540-550.

Fink P, Von Elert E. 2006. Physiological responses to stoichiometric constraints: nutrient limitation and compensatory feeding in a freshwater snail. Oikos. 115:484-494.

Fulton RS. III. 1988. Grazing on filamentous algae by herbivorous zooplankton. Freshwater Biology. 20:263- 271. 
Hall RO Jr, Tank JL, Dybdahl MF. 2003. Exotic snails dominate nitrogen and carbon cycling in a highly productive stream. Frontiers in Ecology and the Environment. 1:407- 411.

Hall RO Jr, Dybdahl MF, Vanderloop MC. 2006. Extremely high secondary production of introduced snails in rivers. Ecological Applications.16(3):1121-1131.

Hart DD. 1981. Foraging and resource patchiness: field experiments with a grazing stream insect. Oikos. 37:46-52.

Haynes A, Taylor B JR. 1984. Food finding and food preference in Potamopyrgus jenkinsi (EA Smith) (Gastropoda: Prosobranchia). Arch. Hydrobiology. 100(4):479-491.

Karasov WH, Martinez del Rio C. Physiological Ecology. Princeton (NJ): Princeton University Press; 2007.

Kerans, BL, Dybdahl MF, Gangloff MM, Jannot JE. 2005. Potamopyrgus antipodarum: distribution, density, and effects on native macroinvertebrate assemblages in the Greater Yellowstone Ecosystem. Journal of North American Benthological Society. 24(1):123-138

Krist AC, Dybdahl MF. 2005. The invasive New Zealand mudsnail, Potamopyrgus antipodarum, reduces growth in the native snail. Fossaria sp. In: Harlow HJ, Harlow MA editors. UW NPS Research Station Annual Report. 29:42-48.

Krist AC, Charles CC. 2012. The invasive New Zealand mudsnail, Potamopyrgus antipodarum, is an effective grazer of algae and altered the assemblage of diatoms more than native grazers. Hydrobiolgia. 694(1):143-151.

McCarthy SD, Rafferty SP, Frost PC. 2010. Responses of alkaline phosphatase activity to phosphorus stress in Daphnia magna. The Journal of Experimental Biology. 213:256261.

Peckarsky B. 1996. Alternative predator avoidance syndromes of stream-dwelling mayfly larvae. Ecology 77(6):1888- 1905.
Riley LA, Dybdahl MF, Hall RO. 2008. Invasive species impact: asymmetric interactions between invasive and endemic freshwater snails Journal of North American Benthological Society. 27:509-520.

Sala OE, Chapin III S, Armesto JJ, Berlow E, Bloomfield J, Dirzo R, Huber-Sanwald E, Huenneke LF, Jackson RB, Kinzig A, Leemans R, Lodge DM, Mooney HA, Oesterheld M, Poff NL, Sykes MT, Walker BH, Walker M, Wall DH. 2000. Global biodiversity scenarios for the year 2100 . Science, 287:1770-74.

Stearns SC. 1992. The evolution of life histories. Oxford: Oxford University Press; 1992.

Sterner RW, Elser JJ. The Biology of Elements from molecules to the Biosphere. Princeton: Princeton University Press: 2002.

Suzuki-Ohono Y, Kawata M, Urabe J. 2012. Optimal feeding under stoichiometric constraints: a model of compensatory feeding with functional response. Oikos. 121:569-578.

Tibbets TM, Krist AC. Hall Jr., RO, Riley LA. 2010. Phosphorus-mediated changes in life history traits of the invasive New Zealand mudsnail (Potamopyrgus antipodarum). Oecologia. 163:549-559.

Tilman D. Resource Competition and Community Structure. Princeton: Princeton University Press; 1982. 